\title{
ПЕРЕДУМОВИ СТВОРЕННЯ СПЕЦІАЯІЗОВАНИХ ШКІЛ МИСТЕЦЬКОГО СПРЯМУВАННЯ В УРСР (30-70 РР. ХХ СТ.)
}

У статті проаналізовано вплив освітніх реформ в Україні радянського періоду (30-70-х років ХХ століття) на створення спецціалізованих шкіл мистец̧ького спрямування, якому передував розвиток навчальних предметів мистецьького спрямування в масовій школі («Співи» та «Малювання»).

Здійснено ретроспективний аналіз проблеми в широких хронологічних межах, вивчено зміст тогочасних навчальних програх із зазначених предметів. У результаті виявлено причини i характер кількісних змін у погодинному навантаженні для предметів мистецького спрямування у навчальних планах шкіл з украйнською та російською мовами навчання.

Аналіз джерельної бази дав підстави констатувати: незважаючи на різні цілі, котрі висувала держава в роки становлення «крайни трудящцих перед шкільною освітою, періодччне включення $і$ вилучення з навчальних планів різних предметів, музичне та образотворче мистецьтво не тільки не зникло, але й твердо закріпилося в переліку базових дисицилін шкіл загальної середньої освіти. Це обумовлювалося, передусім, розумінням значного впливу зазначених видів мистецтв на формування інтегрованих знань в учнів, визнанням їх значного потенціалу щодо розширення світогляду радянської людини, яка відповідно до визначених державою меж мала формуватися як висококультурна особистість. Також простежувався ӥхній значний впхив на всебічне, зокрема, на естетичне виховання дитини, оскільки у процесі навчання розвивалися художні смаки, моральні та духовні якості, почуття прекрасного, відчуття гармонї̈.

Простежено нерівномірність розподіху годин на вивчення предметів художньоестетичного цииклу: від поступового збільшення (50-ті рр. минулого століття) навчальних годин на викладання «Музики» та «Малювання», а пізніше (60-ті рр. минулого століття) до їх зменшення. Проаналізовано характер стандартизації навчальних програх мистецького спрямування для загальних середніх шкіл усіх республік Радянського Союзу, чіткий репертуарний план та його відповідність ідеологї̈ тогочасної влади.

Ключові слова: навчальні предмети мистецьвкого напряму, малювання, музика, естетичний розвиток, навчальні плани, мистецтво в щколі.

Постановка проблеми. Важдиву роль у формуванні духовності, моральних цінностей молодого покоління та поваги до національної культури відіграють навчадьні предмети мистецького спрямування, що викладаються у закладах загадьної середньої освіти, зокрема такі як музика й образотворче мистецтво. На цих навчальних заняттях у школярів відбувається розвиток естетичного смаку, емоційного інтелекту, що сприяє формуванню нестандартного креативного мислення. Сьогодні зазначені завдання продуктивно розв'язують спеціалізовані школи, де вивчення предметів мистецького спрямування відбувається за розширеною, поглибленою програмою.

Аналіз досліджень. До питань мистецької шкільної освіти у своїх наукових дослідженнях зверталися І. Гринчук, Л. Масол, Г. Падалка, О. Рудницька, І. Сотська, 1. Хлєбнікова та ін. Вони стверджують, що у 50-60-х роках XX століття були створені

*C) Шепель A. B.

*(C) Примакова В. В.

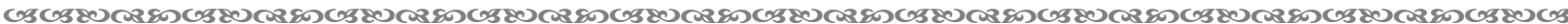
268 
лише передумови до розвитку предметів мистецьких дисциплін у вітчизняних загальноосвітніх школах. Теоретичними і практичними здобутками розвитку мистецтва у школі ділилися $\Lambda$. Безбородова, А. Болгарський, М. Маліборський, О. Рудницька та ін. Загалом тема розвитку спеціалізованої освіти мистецького напряму в школах України розкрита широко. Водночас вважаємо важдивим прослідкувати історико-педагогічний розвиток мистецьких дисциплін у шкільній освіті України в ретроспективі. Вивчення попереднього досвіду навчання художньо-естетичних та мистецьких дисциплін сприятиме вирішенню нових завдань, що постають перед сучасною мистецькою освітою.

Мета статті - визначення історичних передумов створення на території України спеціалізованих шкіл мистецького спрямування у XX столітті.

Відповідно до мети, ми окреслили такі завдання: розгдянути освітні нововведення, що відбувалися у 30-70-х роках минулого століття в українській школі; проаналізувати навчальні плани і програми шкільних предметів художньо-естетичного циклу; визначити причини і характер змін в освіті, що стали передумовами для створення закладів для поглибленого вивчення дисциплін мистецького спрямування.

Викдад основного матеріалу. 30-50-ті роки XX стодіття прийнято вважати особливим періодом реформування шкільної освіти в Україні. Зокрема, Л. Пироженко зазначає, що в той час на зміну відносно демократичним, педоцентричним принципам прийшла стандартна єдина для всіх, уніфікована школа, ознаками якої були єдиний зміст освіти, класно-урочна система, єдині для всіх підручники з відповідною для того часу ідеологією, система оцінювання тощо. Вчена стверджує, що держава вже повністю контродювала сферу освіти; спостерігався певний занепад у сфері творчо-педагогічної діяльності, натомість панував розквіт стандартизації, авторитарності та занурення в ідеологію марксистсько-ленінського вчення в освіті. Дослідниця також підкреслюе, що неготовність вчителів до впровадження нового змісту навчання, до роботи в нових умовах стандартизованої предметної класно-урочної системи долади за допомогою планування [11].

Оскільки групову форму роботи замінив урок у сталому учнівському колективі за сформованим розкладом, з'явилася можливість чіткого розмежування індивідуального i колективного навчання, конкретизації та усвідомлення вимог до проведення уроку, що став основною формою організації шкільного навчання. До навчальних планів уводилися переважно ті предмети, які, з погляду керівництва галуззю, допомагали формувати в учнів матеріалістичну картину світу.

Важливими реформами у 30-70-х роках минулого століття стали такі, у результаті яких відбувся перехід спочатку з 3-річної на обов'язкову 4-річну початкову освіту, а потім повернення до 3-річної початкової освіти. Завершення навчання у 7-річній школі давало право вступити до технікуму, а повна середня освіта 10-річної школи надавала можливість стати студентом одного з вищих навчальних закладів. Упродовж періоду активно утверджувалася русифікація освіти в навчальних закладах УРСР; запроваджувадися ідеї колективізму і політизації завдяки активній діядьності піонерських та комсомодьських організацій. Одним із основних завдань освіти цього періоду стало формування нової радянської людини [11]. I така людина мала бути всебічно розвиненою.

Мистецький напрям у навчальному плані I концентру 1929/30 н. p. був представлений «Співами» (2 години на тиждень) і викладався 31 по 4 клас, тоді як малювання не виокремдювалося, а входило до комплексів, які буди розроблені на кшталт інтегрованих курсів [5]. Таким чином, ставилася мета дати дітям початкові знання про мистецтво, насамперед музичне.

У навчальному плані початкової школи на 1932/33 н. р. у переліку навчальних предметів замість «Співів», поряд із предметами основних наук, з'явдяеться «Музичне виховання», погодинне навантаження якого змінене до 1 год. на тиждень у 1-3 класах, us 269 
і 2 год. на тиждень у 4 класі [11]. Із уведенням на початку 30-х років XX століття нового змісту освіти виділяються два навчальні предмети мистецького напряму «Малювання» та «Співи», погодинне навантаження кожного у обсязі 1 год. на тиждень розраховано на вивчення у всій початковій і частково у середній школі [5]. Проте навіть наприкінці 30-х років минулого століття навчальні програми цих предметів мали лише загальні рекомендації щодо тем, які пропонувалися до вивчення. На заняттях з малювання займалися малюванням 3 натури, зображувади теми 3 повсякденного життя або літературних творів [8]. На уроках музики займалися хоровим співом, ознайомлювалися з елементарним рівнем сольфеджіо та музичної грамоти, слухали музичні твори [9]. Навчання 3 обох предметів було розраховано на 5 років (3 1 по 5 класи) [5].

Для дітей, обдарованих в галузі мистецтва (музика, образотворче мистецтво), у 30-х роках минулого століття з метою посиленого розвитку їхніх творчих здібностей почали з'являтися відповідні школи. У новостворених навчальних закладах поєднувалося викладання загальноосвітніх предметів зі спеціальною підготовкою відповідного мистецького профілю. Найчастіше такі шкоди мади у своєму складі інтернати для дітей з інших міст та багатодітних родин. Із цих навчальних закладів випустили багато успішних митців, які стади не тільки відомими музикантами та художниками, а й талановитими педагогами у галузі мистецької освіти. Сьогодні школи для обдарованих дітей у галузі мистецтва, створені у 30-х роках минулого століття, продовжують свою роботу. Після реформування та трансформацій вони оновили зміст навчання, змінили назви та зберегли мету - потужний розвиток мистецьких здібностей талановитих дітей.

Нині вони відомі в Україні та далеко за ії межами. Це Київська середня спеціалізована музична школа-інтернат ім. М. Аисенка, Дьвівська середня спеціалізована музична школа-інтернат ім. С. Крушельницької, Одеська середня спеціалізована музична школа-інтернат ім. професора П. Столярського, Харківська середня спеціалізована музична школа-інтернат, Державна художня середня школа ім. Т. Г. Шевченка та ін.

У першій половині 40-х років минулого століття події Другої Світової війни пригальмували реформи в освіті. 329814 початкових і середніх шкіл, які функціонували на початку 1941 року, на час завершення війни майже чверть була ліквідована, а близько 10 тис. навчальних закладів були зруйновані частково [4, с. 54-55]. Унаслідок цього перед Міністерством освіти УРСР постало питання про відновлення та розширення мережі шкіл для організації навчання різних верств населення. Водночас у початковій школі зменшується навантаження, закріплюється цифрова (п'ятибальна) система оцінки знань учнів.

У середній школі переважає знаннєвий підхід до формування змісту освіти. Важдивими вважають самі знання та їх обов'язкове засвоєння. Тому зміст освіти у навчальних програмах та планах подекуди відірваний від життя, особистих інтересів і досвіду учнів. Навчальні предмети мистецького напряму залишаються у навчальному плані середніх шкіл. I якщо «Співи» вивчаються 1 год. на тиждень у 1-5 класах, то у «Малюванні» змінюється навантаження: 1 год. на тиждень у 1-2 класах, по 0,5 год. У 3-4 класах, 1 год. у 5 класі [3]. Закріплюеться репродуктивний принцип навчання «прослухав-вивчив-відтворив» 3 одночасною наполегливою русифікацією навчання.

Згодом, у 50-х роках минулого століття, відзначається послаблення тоталітарного контролю у різних сферах життя, що в свою чергу позначилося і на розвитку загальної середньої освіти.

У той час розробляються проєкти положень щодо функціонування різних типів навчальних закладів та навчальні програми і плани до них. У 1956/57 н.р. майже всі школи перейшли на нові навчальні плани, які передбачають підготовку 
старшокласників до роботи в колгоспах та на підприємствах. 3 планів вилучаються та вводяться різні навчальні предмети, перебудовуеться їх зміст.

Закон Верховної Ради УРСР «Про зміцнення зв'язку шкоди 3 життям і про подальший розвиток системи народної освіти в Українській РСР» (1959 р.) затвердив перехід на обов'язкове 8-річне навчання як ще один крок до розвитку загальної середньої освіти. Реалізація основних положень цього закону потребувала трансформації системи масової освіти та впровадження ранньої професіоналізації [11, с.40]. Цей період відзначився переходом деяких шкіл УРСР до диференційованого навчання.

За новими програмами школа готувала учнів до суспільно корисної діяльності в умовах політехнічного навчання, здійснюючи при цьому моральне, фізичне та естетичне виховання. Так утворюються середні трудові політехнічні школи.

Зміни знову торкнулися і навчальних предметів мистецького напряму. Так на 1957/58 н.р. «Малювання» викладалося - 1 год. на тиждень 31 по 6 клас, а «Музика і співи» по 1 год. на тиждень 31 по 11 клас [12, с. 47]. Тобто час на викладання предметів мистецьких дисциплін збільшився. Це свідчить про важдивість завдань змісту навчального матеріалу з цих предметів в загальному розвитку учнів та їх художньоестетичному вихованні. Розширюеться і зміст освіти у вивченні предметів.

Окремі знання 3 мадювання використовувалися для виготовлення виробів декоративно-ужиткового мистецтва, столярних виробів на уроках трудового навчання, на які була спрямована велика увага в той період. Що стосується інших форм навчання мистецького напряму, то 50-60-ті роки XX століття відзначилися потужним розвитком, але у формі гурткової роботи.

Впровадження в школах диференційованого навчання мало свої позитивні результати і було підтримано науковцями. Проте відзначалося перевантаження учнів за деякими профілями, не всі школи мали достатню матеріально-технічну базу для належного рівня такого навчання. У свій час цей підхід до навчання трансформується в організацію шкіл із поглибленим вивченням окремих предметів та, згодом, у створення спеціалізованих шкіл, в яких профільні дисципліни виклададися за спеціальностями.

3 середини 60-х років XX століття обрано курс на виховання освіченого «представника соціалістичного суспільства». Тому у загальній середній освіті акцент із політехнічної освіти переноситься на загальну освіту та розвиток. У 1964/65 н.р. у середніх та восьмирічних школах «Малювання» викладається з 1 до 6 класу, а «Музика і співи» $з 1$ до 8 класу. У 1965/66 н.р. у навчальних планах «Малювання» змінюеться у «Образотворче мистецтво» i разом 3 «Музикою і співами» викладається 1 год. На тиждень з 1 до 6 класу. Того ж року відбувається повернення до 10-річного навчання у школах, що призводить до змін у навчальних програмах і планах загальноосвітніх шкіл [2].

У 1966 році Постанова ЦК КПРС і Ради Міністрів СРСР «Про заходи подадьшого поліпшення роботи середньої загальноосвітньої школи» акцентувала увагу на потребі привести у відповідність зміст освіти щодо розвитку науки, техніки і культури, забезпечити наступність у вивченні навчальних предметів різних наук, створити стабільні підручники та посібники, подолати перевантаження учнів, ввести факультативні заняття (з 7-го класу), розробити заходи щодо покращення естетичного виховання в школі [10, с. 2].

У другій половині 60-х років у навчальних планах середніх шкіл відбувається постійне коливання у кількості років, відведених для вивчення предметів мистецького напряму. Як наслідок цього була потреба у постійному корегуванні викладання навчального матеріалу цих дисциплін.

Розроблення навчальних програм з образотворчого мистецтва, музики і співів було покдадено на міністерство освіти СРСР. Ці програми буди єдиними на всій

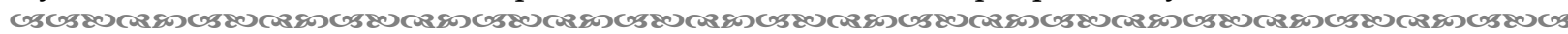
271 
території Радянського Союзу, їх передруковували для шкіл України, не перекладаючи $[11$, с. 140]. Нововведенням у цих програмах стала поява нового розділу «Основні вимоги до знань та умінь учнів», у якому прописувалося, що конкретно повинен вивчити, якими уміннями та навичками із зазначеного предмету має оволодіти учень відповідного року навчання.

Проте реформи 60-х років минулого століття в цілому не внесли істотних змін у навчальні програми образотворчого мистецтва та музики. Аише наприкінці 60-х на початку 70-х років минулого століття вони отримали новий зміст у зв'язку із посиленням уваги до естетичного виховання учнів у загальноосвітніх школах.

«Музика» як навчальний предмет виховувала естетичні смаки і почуття, розвивала емоційний інтелект учнів. Формування музичного слуху, вокальних даних, знайомство із музичними творами видатних композиторів, як сучасних, так і класиків, тренування почуття ритму, удосконалення музичної пам'яті у комплексі утворювало потребу уподальшому спілкуванні 3 музикою, а у деяких учнів провокувало бажання до подадьшого здобуття музичної освіти.

Програма кожного року навчання містила три розділи: хоровий спів, репертуар для хорового співу, основи музичної грамоти та практичні завдання з содьфеджіо. Завдяки міжпредметним зв'язкам, закладеним у програму, використовувалися знання 3 дітератури, історії музичних творів пов'язували 3 темами уроків. Відзначалася варіативність у переліку музичних творів для прослуховування учнями та хорового співу. У досліджуваному періоді додавадися і вилучалися твори, рекомендовані для використання у навчальному процесі, пропонувалися пісні, актуальні для того часу. За структурою і завданнями курс музики майже не змінився [6].

За програмою «Образотворче мистецтво» учні повинні були навчитися зображувати об'ємні предмети засобами світлотіні, овододіти початковими практичними знаннями відображення перспективи у малюнках. Програма мала чотири розділи у кожному класі: малювання на різноманітні теми, малювання 3 натури, ознайомлення 3 творами художників минулого і сучасності, декоративна робота. Метою викладання образотворчого мистецтва у загальноосвітній школі 70-х років XX ст. було формування естетичного ставлення до дійсності, природи, суспільної корисної праці (як надалі вибору майбутньої професії), розвиток художніх смаків, практичних навичок, умінь, виховання любові до мистецтва, формування прагнення до естетичних ідеалів, підживлення інтересу та потреби у спілкуванні з мистецтвом, сприяння ідейнополітичному, моральному, естетичному, художньому розвитку школярів [7].

У цей період у змістовній складовій курсів «Музика» та «Образотворче мистецтво» простежується посилення іiі теоретичної частини. Ускладнився зміст матеріалу щодо содьфеджіо та музичної грамоти, історії та теоретичних основ мистецтва. Годовним завданням обох мистецьких курсів залишався усебічний гармонійний розвиток учнів, розвиток їх здібностей, інтересів, сприяння активному естетичному та моральному вихованню, подальшій профорієнтації.

Висновки. Аналіз динаміки змін погодинного навантаження предметів мистецьких дисциплін у навчальних планах середніх шкіл та поступове ускладнення змісту навчальних програм цих дисциплін в 30-70-х рр. минулого століття дає можливість стверджувати, що в той час створювалися передумови становлення спеціалізованих навчальних закладів мистецького напряму. «Образотворче мистецтво» та «Музика» надійно закріпилися у навчальних планах середніх шкіл, відігравали вагому роль у художньо-естетичному вихованні школярів. За рахунок знань, отриманих на цих заняттях, формувалася творча особистість учня, його унікальне особистісне сприйняття гармонії і краси, художні смаки, моральність і духовність, хоча і поруч зі специфічним репертуаром, сформованим владою. Зміст навчальних програм був спрямований на формування інтересу до мистецьких спеціадьностей, здобуття вмінь та навичок для їхнього практичного використання у житті, часткової профорієнтації. У період

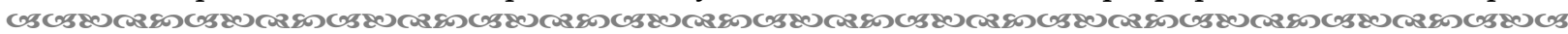
272 
політехнізації школи відзначається увага до мистецьких дисциплін як засобів формування висококультурної особистості. У зв'язку з посиленням уваги до естетичного виховання школярів назрівала потреба у створенні закладів з поглибленим вивченням предметів мистецького спрямування.

Результати дослідження спонукають до подальшого вивчення розвитку художньоестетичного напряму в школах загальної середньої освіти для визначення процесу створення та становлення спеціалізованих шкіл мистецького спрямування та використання педагогічного практичного та теоретичного досвіду в роботі сучасних спеціалізованих закладів освіти цього напряму.

\section{Список використаних джерел:}

1. Вендровская Р. Б. Проблемы формирования учебных планов в советской школе. Советская педагогика. 1987. № 3. С. 94-102.

2. Кашин М. П. Учебные планы средней школы. Москва: НИИ содерж. и методов обучения АНП СССР, 1978. 165 с.

3. Навчальні плани початкової та середньої школи. Київ: Наркомос УРСР, 1939. 23 с.

4. Отчет об учете ущерба, причиненного немецко-фашистскими захватчиками и их сообщиками учреждениям Народного комиссариата просвещения УССР. Центральний державний архів вищих органів влади та управління Украйни. Ф. 166, оп. 15, спр. 61, 55 с.

5. Помагайба В. І. Програми початкової шкоди. Питання початкової освіти: наук.зап. Київ.: Рад.шк., 1963. Т. XXX. С. 30-45.

6. Программы для средней школы. Музыка. 4-7 класс. Київ. 1968. 15 с.

7. Програми для восьмирічної школи. Образотворче мистецтво. 4-6 клас. Київ, 1967. 25 с.

8. Програми середньої школи. Малювання (4-6 клас). Київ, 1937. 12 с.

9. Програми середньої школи. Музика і співи (4-7 клас). Київ, 1937. 15 с.

10. Про заходи дальшого поліпшення роботи середньої загальноосвітньої школи. Постанова ЦК КП України і Ради Міністрів УРСР. Київ, 1967. № 1. С. 1-5.

11. Пироженко А. В. Реформування змісту загадьної середньої освіти (середина 60-х - початок 80-х рр. XX століття): монографія. Київ.: Педагогічна думка, 2013. 304 с.

12. Учебные планы школ системы Министерства просвещения УССР на 1957/58 уч. год. Київ, 1957. 55 c.

\section{References:}

1. Vendrovskaia, R. B. (1987). Problemy formirovaniia uchebnykh planov v sovetskoi shkole [Problems of the curricula formation in the Soviet school]. Sovetskaia pedagogika, 3, 94-102 [in Russian].

2. Kashin, M. P. (1978). Uchebnye plany srednei shkoly [Curricula of a secondary school]. Moskva: NII soderzh. i metodov obucheniia ANP SSSR [in Russian].

3. Navchalni plany pochatkovoi ta serednoi shkoly [Curricula of a primary and secondary school]. (1939). Kyiv: Narkomos URSR [in Ukrainian].

4. Otchet ob uchete ushcherba, prichinennogo nemetcko-fashistskimi zakhvatchikami i ikh soobshchikami uchrezhdeniiam Narodnogo komissariata prosveshcheniia USSR [Report on the accounting of damage caused by the Nazi invaders and their accomplices to the institutions of the People's Commissariat of Education of the Ukrainian SSR] (Fund 166. Inventory 15. File 61). Central State Archives of Supreme Bodies of Power and Government of Ukraine (TsDAVO of Ukraine) [in Russian].

5. Pomahaiba, V. I. (1963). Prohramy pochatkovoi shkoly. Pytannia pochatkovoi osvity: nauk. zap. [Primary school programs. Issues of primary education: scientific notes]. (Vol. 30). Kyiv: Rad. shk. [in Ukrainian].

6. Programmy dlia srednei shkoly. Muzyka. 4-7 klass [Syllabus for a secondary school. Music. Grades 4-7]. (1968). Kyiv [in Russian].

7. Prohramy dlia vosmyrichnoi shkoly. Obrazotvorche mystetstvo. 4-6 klas [Syllabus for the eight-year school. Art. Grades 4-6]. (1967). Kyiv [in Ukrainian].

8. Prohramy serednoi shkoly. Maliuvannia (4-6 klas) [Secondary school syllabus. Drawing (grades 4-6)]. (1937). Kyiv [in Ukrainian]. 
9. Prohramy serednoi shkoly. Muzyka i spivy (4-7 klas) [Secondary school syllabus. Music and singing (grades 4-7)]. (1937). Kyiv [in Ukrainian].

10. On measures to further improve the work of secondary schools. Resolution of the Central Committee of the Communist Party of Ukraine and the Council of Ministers of the USSR. (1967). Kyiv [in Ukrainian].

11. Pyrozhenko L.V. (2013). Reformuvannia zmistu zahalnoi serednoi osvity (seredyna 60-kh - pochatok 80-kh rr.. XX stolittia): monohrafiia [Reforming the content of general secondary education (mid 60s - early 80s XX century): monograph]. Kyiv: Pedahohichna dumka [in Ukrainian].

12. Uchebnyye plany shkol sistemy Ministerstva prosveshcheniya USSR na 1957/58 uch. god [Educational syllabus of the system of the Ministry of Education of the USSR for the 1957/58 school year]. (1957). Kyiv [in Russian].

Shepel A. V., orcid.org/0000-0003-2582-8982

Prymakova V. V., orcid.org/0000-0002-8914-6748

PRECONDITIONS FOR THE CREATION OF SPECIALIZED SCHOOLS OF ART ORIENTATION IN THE USSR (30-70S OF THE XX CENTURY)

The article analyzes the influence of educational reforms in Ukraine in the Soviet period (30-70s of the XX century) on the creation of specialized art schools, which was preceded by the development of art subjects in public school ("Singing" and "Drawing").

A retrospective analysis of the problem in a wide chronological range is accomplished and the content of that time programs in these subjects is studied. As a result, the reasons and nature of quantitative changes in the hourly load for art subjects in the curricula of schools with Ukrainian and Russian languages of study are identified.

The analysis of the source base gave grounds to state: despite the various goals set by the state during the years of "workers' country" formation before school education, periodic inclusion and exclusion from the curricula of various subjects, Music and Art not only did not disappear but also firmly established in the list of basic disciplines of general secondary education schools. This was primarily due to the understanding of the significant influence of these arts in the formation of integrated knowledge in students, the recognition of their significant potential to expand the worldview of the Soviet man, who according to state limits was to be formed as a highly cultured person. There was also a significant influence on the comprehensive, in particular, on the aesthetic raising of a child, as in the process of learning developed artistic tastes, moral and spiritual qualities, a sense of beauty, a sense of harmony.

The irregularity distribution of hours for the study of artistic and aesthetic cycle subjects: from the gradual increase (50s of the last century) of training hours for teaching "Music" and "Drawing", and later (60s of the last century) to their reduction are looked over. The nature of standardization of art programs for general secondary schools of all republics of the Soviet Union, a clear repertoire plan and its compliance with the ideology of that government are analyzed.

Key words: art subjects, drawing, music, aesthetic development, curriculums, art at school.

Дата надходження статmі: 14.01.2021 p.

Рецензент: доктор педагогічних наук Чумак $\Lambda$. В. 